\title{
Time and Space in Between: Time Zones, Languages, and Cultures in Transcarpathia (Ukraine)
}

\author{
István CSERNICSKÓ \\ University of Pannonia (Veszprém, Hungary) and Ferenc Rákóczi II Transcarpathian \\ Hungarian College of Higher Education (Beregszász, Ukraine) \\ csernicsko.istvan@kmf.uz.ua \\ Csilla FEDINEC \\ Hungarian Academy of Sciences, Centre for Social Sciences, Institute for Minority \\ Studies (Budapest, Hungary) \\ Fedinec.Csilla@tk.mta.hu
}

\begin{abstract}
In this paper, based on the data of a sociological research and the analysis of the linguistic landscapes of six Transcarpathian cities, we have illustrated that in Transcarpathia a significant part of the population-regardless of ethnicity - live their lives not according to the official "Kyiv time" (EET; UTC+2) but according to the "local time" (CET; UTC+1). Even the names of the two times are distinguished in the local language use in Ukrainian, Hungarian, and Russian languages alike. The difference between official central time and "local time" appeared in Transcarpathia when the region became annexed to the Soviet Union. Yet, before the Second World War, each state in the region used CET. The Soviet power introduced Moscow time zone (MSK; UTC+3) of two hours ahead. The distinction between "local time" and central time was maintained when Transcarpathia became part of the newly independent Ukraine. The population in the region was urged to use a different time zone for a relatively short time from a historical point of view. The persistence of "local time" is also strengthened by the fact that it contributes to the image of Transcarpathia as a particular, specific region of Ukraine.
\end{abstract}

Keywords: Transcarpathia, local time, official time, regional identity

\section{Time zones and politics}

Time zones, introduced at the International Meridian Conference organized in Washington D.C. in 1884, are those regions of the Earth's surface where timekeeping devices (clocks) show the same time. In principle, time zones are set in relation 
to Coordinated Universal Time (UTC), where the reference point is the prime meridian, that is, the zero degree line of longitude running through Greenwich, near London. In practice, however - although time zones are determined by the geographical lines of longitude -, the extent of specific time zones are also influenced by the political, including administrative, borders of states.

The time established in relation to Coordinated Universal Time and within time zones adjusted to state borders does not necessarily match the local time. For example, on the east coast of China, close to the Pacific Ocean, it is officially noon at the same time as on the western ends of the vast country; however, it is easy to see: the sun cannot stand at high noon at the same time above locations lying thousands of kilometers away from each other from the east to the west. Precisely because state and administrative boundaries do not coincide with the time zones defined on a geographical basis, there may be greater or smaller differences between the centrally specified official time and the "local time" adjusted (more) to the position of the sun.

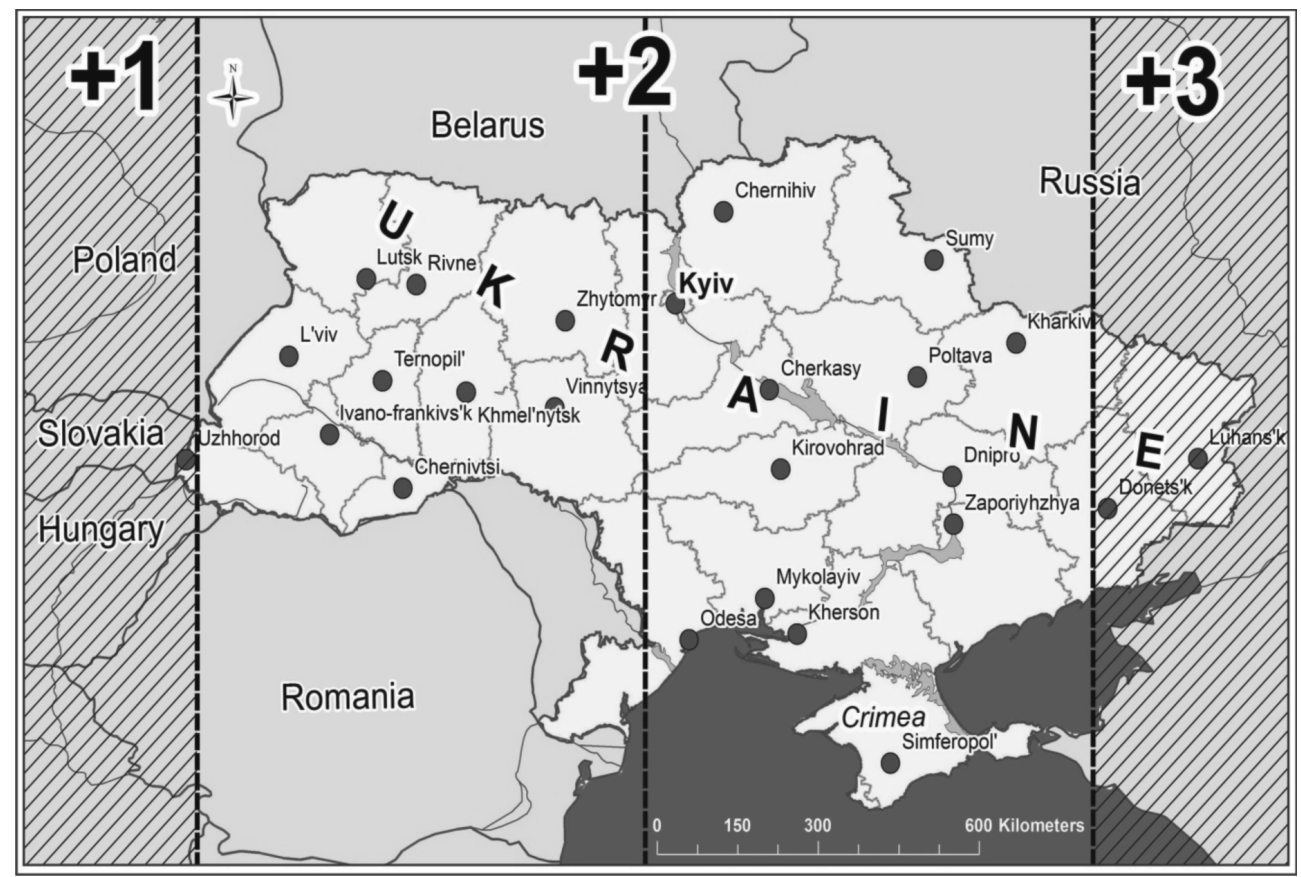

Based on: http://www.ukrrudprom.com/digest/Ukraina_otkazalas_git_po_donetskomu_vremeni. html (accessed on: 28 January 2019)

Figure 1. Geographical time zones on the territory of Ukraine 
Nevertheless, because of the unification of time measurements based on practical considerations, the eastern and western peripheries still have to live in the same time, EET (UTC+2), just like the centre. However, this is not always easily reconciled with the natural sense of time and custom. In this paper, we demonstrate how "local time" is measured in the western part of Ukraine, Transcarpathia. It will be shown how the "original inhabitants" call the official and the informal "local time" and how the duality of time is displayed in the public space.

Most of the territory of Ukraine - over 90\% (Boiko et al. 2016: 68) - belongs to the Eastern European time zone (EET), which means a +2-hour difference from UTC. Thus, when in Greenwich it is 12 o'clock (noon), it is already 14:00 $(\mathrm{UTC}+2)$ in Kyiv. However, the eastern and western ends of Ukraine stick out of the Eastern European Time (EET) (Figure 1). In the east, the Luhansk region completely, the majority of Donetsk County, and the eastern area of Kharkiv County can geographically be classified into the Moscow time zone (MSK, which is UTC+3), whereas the western corner of Transcarpathia rather belongs to the Central European time zone (CET, which is UTC+1).

\section{What was the time in Transcarpathia as part of the Soviet Union?}

The territory of present-day Transcarpathia belonged to several states over the past hundred years. The anecdote of an elderly Transcarpathian man, who "turned up" in a number of countries without actually leaving his native village, is generally known in international academic literature (Batt 2002: 155). During the $20^{\text {th }}$ century, the region was part of the Kingdom of Hungary belonging to the Austro-Hungarian Empire; after World War I, of the first Czechoslovak Republic, then of the Kingdom of Hungary; after World War II, it was annexed to the Soviet Union, and since 1991 it has been part of the independent Ukraine (Table 1). Transcarpathia became a separate political region in the $20^{\text {th }}$ century, as part of Czechoslovakia in the interwar period. More than 80 percent of Transcarpathia's inhabitants speak Ukrainian as their native language, while Hungarian is the native language of $12.65 \%$, Russian of $2.9 \%$, and Romanian of $2.57 \%$ of the population. Each of the other linguistic minorities constitutes less than $1 \%$ of the population. A particular feature of Transcarpathia is the presence of an ethnic group that is not officially recognized in Ukraine - the Rusyns. In the most recent Ukrainian census (2001), Rusyn was not even included among the various selectable ethnic categories. 
Table 1. State affiliations of present-day Transcarpathia during the $20^{\text {th }}-21^{\text {st }}$ centuries

\begin{tabular}{lcc}
\hline State affiliation & Period & Official time zone \\
\hline $\begin{array}{l}\text { Kingdom of Hungary within } \\
\text { the Austro-Hungarian } \\
\text { Monarchy }\end{array}$ & $1867-1918$ & CET (UTC+1) \\
\hline Czechoslovak Republic & $1919-1938 / 1939$ & CET (UTC+1) \\
\hline Kingdom of Hungary & $1939-1944$ & CET (UTC+1) \\
\hline Soviet Union & $1946-1991$ & MSK (UTC+3) \\
\hline Ukraine & since 1991 & EET (UTC+2) \\
\hline
\end{tabular}

The changes of state affiliation did not only alter the state borders but the capital, the official language (Csernicskó and Ferenc 2014: 399-425), and the currencies, as well (Csernicskó and Beregszászi 2019). For the purposes of this paper, it is relevant that - as the Kingdom of Hungary belonging to the Austro-Hungarian Empire, the Czechoslovak Republic, and the Kingdom of Hungary invariably used Central European time (CET) - the first discrepancy between the biological clock of Transcarpathians and the official time following political borders was experienced after the region had become annexed to the Soviet Union (Table 1). In the area of today's Transcarpathia, Moscow time was introduced on 5 November 1944. Moscow time was strongly used throughout the whole territory of Soviet Ukraine. However, in unofficial everyday life, peoples of Transcarpathia continued to use their traditional time: the CET. Thus, the population of the region was urged to use a different time zone for a relatively short time from a historical point of view.

In the private sphere, the use of CET was also supported by the appearance of television. The Czechoslovak television broadcasts were available in Transcarpathia from 1953 and the Hungarian ones from 1957. However, the Russian and Ukrainian broadcasts of the central Soviet television broadcasters reached Transcarpathia only a decade later. ${ }^{1}$ During the existence of the Soviet Union, the Moscow and Kyiv radio and television broadcasts - placing the propaganda of communist ideology over everything else - were unenjoyable compared to the radio and TV programmes of neighbouring Czechoslovakia and Hungary, receivable in most parts of Transcarpathia. That is why the majority of the Transcarpathian population were listening to and watching Czechoslovak and Hungarian radio and television broadcasts (as well).

The two western neighbouring countries have opened the window of western societies through television and radio for the Soviet citizens living in Trans-

1 Hereshko, Oleksandr. Jak NSTU mozhe zberegty Zakarpattja v ukrai'ns'komu informacijnomu prostori [How NSTU can save Transcarpathia in the Ukrainian information space]. Zakarpattya Onlajn, 25.07.2017. http://zakarpattya.net.ua/News/171456-IAk-NSTU-mozhe-zberehtyZakarpattia-v-ukrainskomu-informatsiinomu-prostori (accessed on: 28 January, 2019). 
carpathia. While the Soviet television broadcasted primarily political propaganda, the Hungarian and Czechoslovakian televisions also featured American, West German, and British films and series. Transcarpathians from the western side of the Carpathians were also informed about the expected weather conditions from the radio and television broadcasts of the neighbouring countries as forecasts from the other side of the mountains were less accurate. ${ }^{2}$ The Hungarian daily newspaper of the region, Kárpáti Igaz Szó [Carpathian True Word], weekly announced not only the Soviet television programme but also the Czechoslovak and Hungarian ones; the latter, of course, appeared in CET. In a period when the timing of the duties of everyday life was influenced by the starting date of popular television series, the use of CET became part of the daily routine for many Transcarpathians, and it still remains so. Perhaps that is why the situation had evolved, about which the Hungarian writer and poet living in Uzhhorod, Károly Balla D., wrote in one of his essays that the average person living in Transcarpathia "has never been completely transferred to Moscow time. [...] When he was spoken to in Hungarian, he gave the Hungarian time, when in Russian, then the Moscow time, regardless what time his watch displayed" (Balla 1993: 84). ${ }^{3}$

The two-hour difference between the official $(\mathrm{UTC}+3)$ and the local $(\mathrm{UTC}+1)$ time had led to the development of a specific time perception strategy in Transcarpathia with its related linguistic forms. The official Moscow time had its own designation in Russian, Ukrainian, and Hungarian as well (Russian: 'po Moskovski', Ukrainian: 'za Moskovs'kym chasom', Hungarian: 'Moszkva szerint' [according to Moscow]). Similarly, the time used in Transcarpathia had its own name in all three languages (Russian: 'po mestnomu', Ukrainian: 'za miscevym chasom', Hungarian: 'helyi idő szerint' [according to /informal/ local time]). In official, formal situations of language use, Transcarpathians used the official (Moscow) time (UTC+3). Conversely, in informal private discussions, they used the informal local time, or when the situation was not clear they added a distinctive phrase which made it clear whether the time was told 'according to Moscow' or 'according to local time'.

A parallel example of marking the time is an invitation card shown in Figure 2, where, according to the Ukrainian text, guests were invited to the wedding dinner at 19:00 (7:00 p.m.). The Hungarian text also displays 19:00, but there is a distinguishing phrase 'm. idő sz.' (acc. M. time = according to Moscow time). Its function is to indicate that guests should appear at the event not at 7 o'clock

2 Pukish, Volodymyr. Jake "vikno v svit” maly zakarpatci v SRSR: Presa, radio- ta telekanaly "krai'n narodnoi' demokratii”" ta I'h rol' na radjans'komu Zakarpatti [What kind of "window to the world" had Transcarpathians in the USSR: Press, radio, and TV channels of "countries of popular democracy" and their role in the Soviet Transcarpathia]. Zakarpattya Onlajn, 10.08.2011. http://zakarpattya.net.ua/Blogs/86024-IAke-vikno-v-svit-maly-zakarpattsi-v-SRSR (accessed on: 28 January 2019).

3 Translation into English by the authors of the article. 
in the evening but at 5 o' clock in the afternoon, according to local time. This distinction would not have been necessary if everyone in Transcarpathia had used official Moscow time in those days.

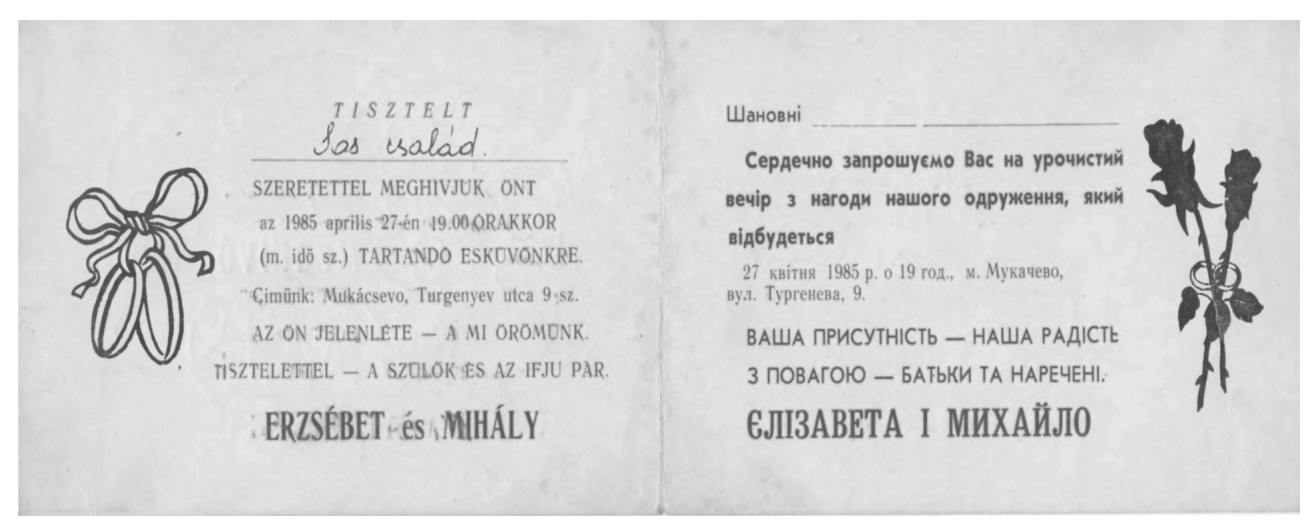

Figure 2. Dual marking of time on a Transcarpathian wedding invitation from 1985

The difference between the official and the informal "local time" may be interpreted as a differentiation between "us" ("original inhabitants") and "them" (settlers), as a disguised mark of identity. Officials settled in Transcarpathia by the Soviet authorities, officers of the various armed forces, party workers, engineers, etc. were not familiar with the Transcarpathian specificities of timekeeping. This is why the practice could have developed where Transcarpathians (Slavs and non-Slavs alike) amongst each other frequently referred to timekeeping different from the official time; instead they told the time in Ukrainian аs 'по нашому' or in Hungarian as 'miszerintünk' (according to us). The words 'наші' (Ukrainian, ours) and 'mi' (Hungarian, we) mean 'Transcarpathians, locals' ("original inhabitants") as opposed to the "eastern settlers" (Csernicskó 1998: 138, Fedinec and Csernicskó 2017). Using the Central European time has become a symbol of western ties amidst the eastern, foreign Soviet reality.

The Soviet power demanded from party members, officials, and teachers deemed as role models and even from the Soviet people of the future, the youth, that watches show the official Moscow time. Then again, to this pressure, Transcarpathians responded by developing a skill: they were able to recall the time from what was shown on their watches. Whether their clocks were set to Moscow time or local time, every Transcarpathian could, off the bat, without any counting or thinking, tell what time it was "according to Moscow" (official time) and "according to us" (informal "local time"). 


\section{How do Transcarpathians measure the time in independent Ukraine?}

Decision No. 15-XII of 11 June 1990 of the Ukrainian Parliament made the Kyiv time (EET) official on the territory of the Ukrainian Soviet Socialist Republic from $1^{\text {st }}$ July. This was one of the first steps on the road to Kyiv's independence from Moscow. Pursuant to the government's Decision No. 272 of 21 September 1990, the summer time remained valid even in the wintertime. In its Decision No. 225 of 29 September 1991, the government ordered to turn clocks back an hour. Thus, from the spring of 1990 until the fall of 1991, there was a long summer in Ukraine. In Transcarpathia, a county council's decision made the Central European time (CET) official, ${ }^{4}$ that is, the informal "local time" already used by many people in the region (Balla 1993: 87).

In independent Ukraine, daylight saving time was introduced on a mandatory basis throughout the country - eliminating the exceptions of Transcarpathia - by Decision No. 2176-XII of 6 March 1992 of the Ukrainian Parliament. The document referred to the article of Decision No. 15-XII of 1990, which defines Kyiv time. In this respect, the 1990 document contained the description of "a second time zone without the addition of one hour", which in 1992 was changed as follows: "Moscow time minus one hour". Since then, the official time in Transcarpathia has become the EET. Compared to the Soviet era, all that changed is that the difference is no longer two hours but only one: EET ("Kyiv time") continues to be UTC+2, while local time remains UTC+1. The designation of the official time in Ukrainian is 'za Kyi’vs'kym chasom', in Hungarian, 'kijevi idő szerint' (according to Kyiv time) or simply 'po Kyi'vs'ki' and 'Kijev szerint' (according to Kyiv). The locals continue to apply confidently the rule settled for decades: whatever their clocks show, they know very well whether they must use the official (Kyiv) or the informal (local) time.

Transcarpathians will not get embarrassed if, for example, they are informed about opening hours by a placard in a shop window as those shown in Figure 3. The Ukrainian-language sign states that the pizzeria is open from 10 a.m. to 10 p.m. according to local time (CET) and from 11 a.m. to 11 p.m. according to Kyiv time (EET).

4 Chas v Ukrai'ni: Roztashuvannja terytorii' Ukrai'ny vidnosno mizhnarodnoi' systemy chasovyh pojasiv. [Time in Ukraine: Location of Ukraine regarding the international system of time zones]; http://energy.gift/chas-ukraini_4459439.html (accessed on: 28 January 2019). 


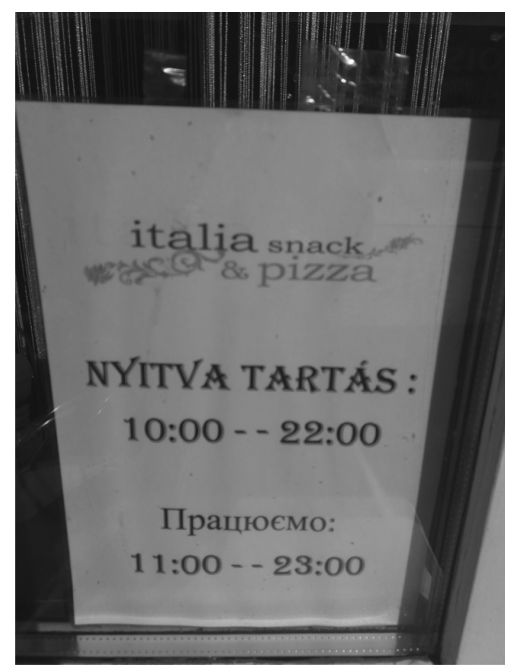

Figure 3. Opening hours indicated according to both local time (CET, UTC+1) and Kyiv time (EET, UTC+2) in the village of Suirte

(Ukr. Cюрте, Hun. Szürte)

\section{The "Local Time” in Linguistic Landscape}

As it can be seen, the duality of official and local time is not limited to orality, but it also exists in the public space, at the level of communal signage (Csernicskó and Laihonen 2016: 8-9). In October 2016, we examined posts and signs, including time signals in six Transcarpathian city centres. We took photographs of notices, posters, etc. indicating the opening hours of shops, restaurants, and offices as well as the start time of events. In the central parts of Uzhhorod/Ungvár, Mukachevo/Munkács, Berehovo/Beregszász, Vynohradiv/Nagyszőlős, Chop/ Csap, and Tiachiv/Técső, a total of 705 photos were taken in which the time was shown in some way (Figure 4).

Four ways of time indication were distinguished. Most of the posts (73.5\%) display the official Kyiv time only, without any indication (i.e. there is no specific reference to the fact that the table should be interpreted according to Kyiv time). In part (14.9\%) of the posts, Kyiv time and local time were both displayed. In a few of such tables, there was an indication to the type of the time, and sometimes there was not. Most of the posts displaying both Kyiv and local time were bilingual: Ukrainian and Hungarian. Only a fraction $(0.5 \%)$ of all boards indicated exclusively the local time, and these were usually Hungarianlanguage posts. Some of the posts (11.1\%) only contained the Kyiv time, but their texts indicated that the hours were displayed according to the official Kyiv time. 


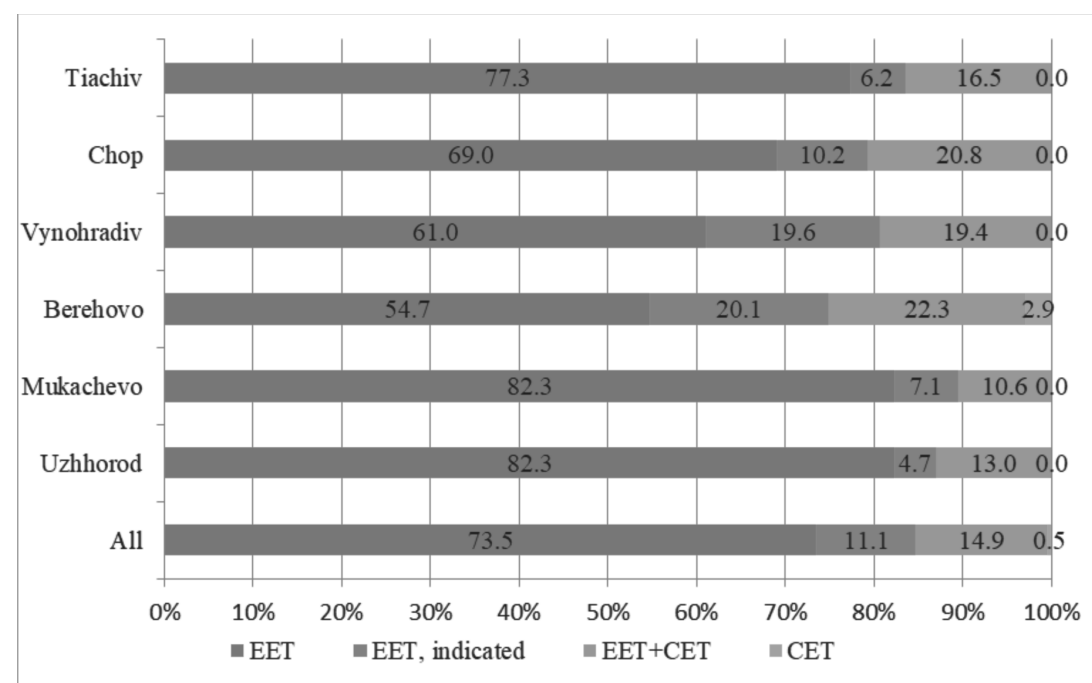

Figure 4. Display of the time on boards, posters, and announcements in six Transcarpathian city centres (October 2016)

Linguistic landscape research often distinguishes between top-down and bottom-up initiatives in shaping the linguistic landscape (Backhaus 2006, Ben-Rafael 2009). The former means that the higher levels (such as central government, state organs, regional or local government) place inscriptions. In the latter case, texts and posts are displayed due to spontaneous initiatives coming from the bottom. These include commercial advertisements, announcements, informative posts, releases of a private nature, graffiti, etc. If the posts displayed in the Transcarpathian cities examined are analysed along this logic, the following can be experienced. Posts containing unmarked Kyiv time are typically top-down in nature and are usually written in the state language (Ukrainian). Most of the posts including indicated Kyiv time are placed by regional or local governments and local units of state companies or firms. These inscriptions may be Ukrainian monolingual, bilingual, or multilingual. The majority of the posts indicating both Kyiv and local time are bilingual (Ukrainian and Hungarian). They may include inscriptions of both top-down and bottom-up in nature, but the latter are in majority. Posts displaying the local time only are exclusively bottom-up in nature. 


\section{Who are using the "local time" in Transcarpathia?}

In the summer of 2016, we carried out a sociological survey in the region, entitled Tandem 2016 with five collaborating research institutes. ${ }^{5}$ A total of 1,212 informants were interviewed at 74 research points. 814 of them answered the questionnaire in Ukrainian and 398 in Hungarian language. 59.6\% (721 people) and $37.6 \%$ (455 people) of the participants declared themselves as ethnic Ukrainians and ethnic Hungarians respectively. 57.9\% (702 people) of the respondents had Ukrainian and 38.7\% (469 people) had Hungarian as their mother tongue. All respondents were Transcarpathians and citizens of Ukraine. The interviewers were students of Transcarpathian universities. The interviewers used standard Ukrainian and standard Hungarian dialect during the survey.

During the interview, field workers asked the respondents what the exact time was and entered the answers into the questionnaire. The interviewer also encoded whether the informant gave his or her answer according to the official Kyiv time (EET) or the unofficial local time (CET). At the end of the survey, respondents were asked again what the time was, their answers being registered in the relevant heading of the questionnaire, with the type of timekeeping they used being encoded.

At the beginning of the survey, $45.0 \%$ of the total sample while at the end $48.9 \%$ used Kyiv time; the majority (55.0\% vs. $51.1 \%$ ), however, used local time. There was a significant difference between those responding the questionnaire in Ukrainian and Hungarian. Respondents who answered in Ukrainian used Kyiv time (EET) in a much higher proportion than those who replied in Hungarian (Table 2).

Table 2. The use of CET and EET at the beginning and at the end of the survey among people answering the questionnaire in Ukrainian and Hungarian

\begin{tabular}{lcccc}
\hline & \multicolumn{2}{c}{$\begin{array}{c}\text { Used official Kyiv time } \\
\text { (EET) }\end{array}$} & $\begin{array}{c}\text { Used informal "local time" } \\
\text { (CET) }\end{array}$ \\
\cline { 2 - 5 } & $\begin{array}{c}\text { Answered in } \\
\text { Ukrainian }\end{array}$ & $\begin{array}{c}\text { Answered in } \\
\text { Hungarian }\end{array}$ & $\begin{array}{c}\text { Answered in } \\
\text { Ukrainian }\end{array}$ & $\begin{array}{c}\text { Answered in } \\
\text { Hungarian }\end{array}$ \\
\hline Beginning of survey & $57.9 \%$ & $18.7 \%$ & $42.1 \%$ & $81.3 \%$ \\
\hline End of survey & $57.4 \%$ & $24.6 \%$ & $42.6 \%$ & $75.4 \%$ \\
\hline
\end{tabular}

There was a significant difference between the individual nationalities concerning the use of Kyiv and local time. Among those who considered

5 Tandem 2016. Kárpátaljai szociológiai felmérés [Tandem 2016. Transcarpathian sociological survey.] http://bgazrt.hu/_dbfiles/htmltext_files/2/0000000432/A5\%20tandem.pdf (accessed on: 28 January 2019). One of the authors of the paper participated in the design of the research and was one of the organizers of the study. 
themselves Russian, Rusyn, or Ukrainian, the use of the official (EET) time was dominant one. On the other hand, among those who declared themselves ethnic Hungarians or ethnic Roma, local (CET) timekeeping was more common (Table 3).

Table 3. The use of EET and CET at the beginning and at the end of the survey according to the ethnicity of the respondents (\%)

\begin{tabular}{lcccc}
\hline & \multicolumn{2}{c}{ Used official Kyiv time (EET) } & \multicolumn{2}{c}{$\begin{array}{c}\text { Used informal "local time" } \\
\text { (CET) }\end{array}$} \\
\cline { 2 - 5 } & $\begin{array}{c}\text { Beginning of } \\
\text { survey }\end{array}$ & End of survey & $\begin{array}{c}\text { Beginning of } \\
\text { survey }\end{array}$ & End of survey \\
\hline Ukrainian & 61.5 & 61.9 & 38.5 & 38.1 \\
\hline Hungarian & 17.5 & 21.3 & 82.5 & 78.7 \\
\hline Russian & 77.8 & 77.8 & 22.2 & 22.2 \\
\hline Rusyn & 66.7 & 62.5 & 33.3 & 37.5 \\
\hline Roma & 25.0 & 25.0 & 75.0 & 75.0 \\
\hline
\end{tabular}

The informants' mother tongue was in strong correlation with the time according to which their watches ran. The majority of Russian and Ukrainian mother-tongue speakers used official Kyiv time, whereas the overwhelming majority of Hungarian mother-tongue speakers preferred the informal "local time" (Figure 5).

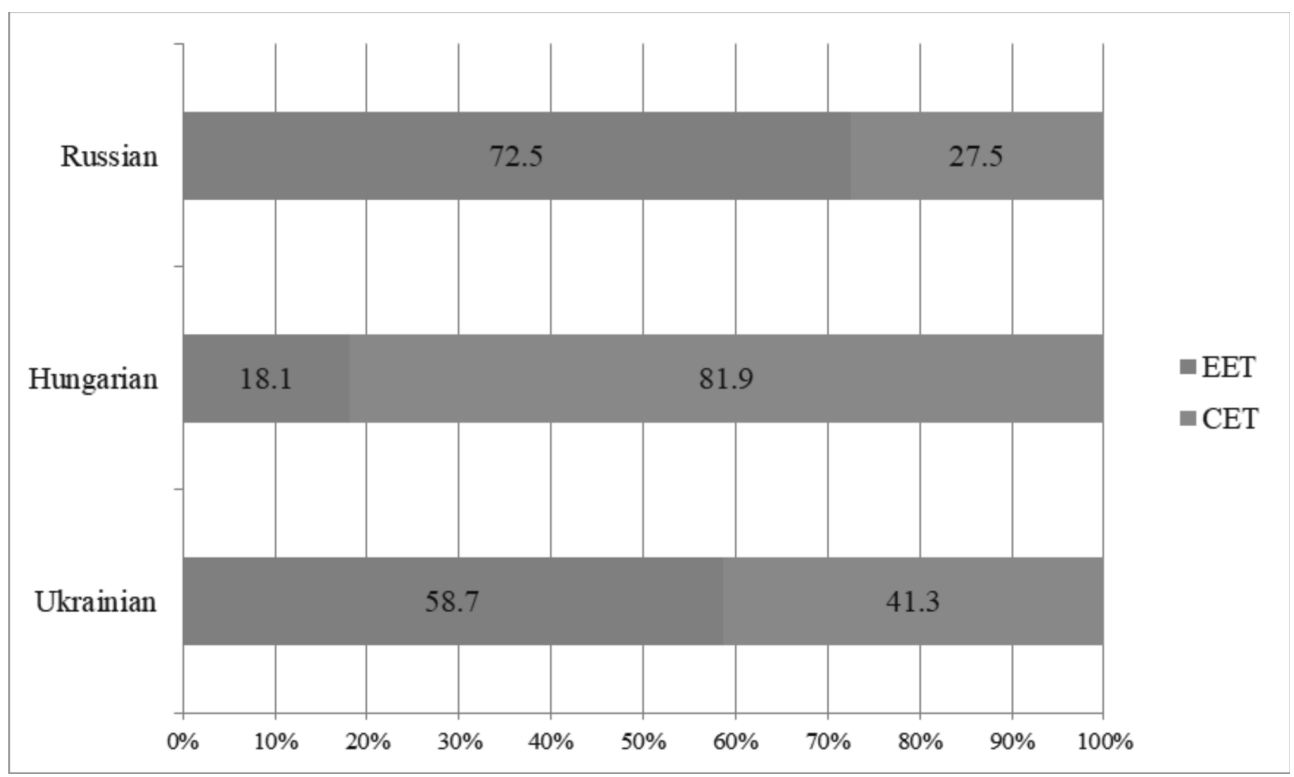

Figure 5. The use of EET and CET at the beginning of the survey according to the mother tongue of the respondents (\%) 
This suggests that the use of local time (CET, UTC+1) is typical mainly among Transcarpathians of Hungarian ethnicity and having Hungarian as their mother tongue, but relatively many people may be found among ethnic Ukrainians and ethnic Russians as well whose clocks do not run according to the official time. The fact that among ethnic Hungarians and Hungarian native speakers the rate of CET users is higher than among Transcarpathian Slavs is not surprising. Several studies have confirmed that Hungarians living in Transcarpathia gather information mostly from the Hungarian television and radio (Csernicskó 2015), and they organize their lives according to the informal "local time". Transcarpathian informal "local time" coincides with the time used in Hungary: both are equivalent to CET.

According to the Tandem 2016 sociological survey, foreign media consumption is very high even today in Transcarpathia. As for the surveyed Ukrainian sample, $24.8 \%$ watch Hungarian television, 19.6\% listen to Hungarian radio, 22.3\% browse Hungarian websites among others, and $22.8 \%$ keep contact with friends and people via Facebook also in Hungarian (Csernicskó 2017).

Interviewers also recorded if the informant commented on his or her answer to the question as to what the time was. A total of 217 people, $18.1 \%$ of the sample, commented on the question as to what the time was $(20.5 \%$ in the Ukrainian subsample and $13.3 \%$ in the Hungarian subsample). Most of the comments related to the specification of the time zone according to which respondents provided their answer. 100 people indicated that they responded "according to Kyiv time"; 90 informants designated the time they told as "local time"; 26 respondents referred to the time they used as "according to us", and only 1 interviewee said that his answer should be understood "according to Hungarian time".

The number of comments shows that the time was unmarked for most of the respondents - whichever time they used. Those who somehow indicated how to interpret the time they told considered important referring to official "Kyiv" or informal "local" time in approximately the same proportion. In the whole sample, villages and cities are reflections of each other: two-thirds of the population in the villages used local time while in the cities Kyiv time. There is no significant difference between villages and cities in the Hungarian sample. In the Ukrainian sample, we find $16 \%$ among town dwellers who used local time.

It can also be seen that the most commonly used designations were "Kyiv time" and "local time". The Ukrainian "по нашому" and the Hungarian "according to us" are likely to have appeared in such a small number because these denominations are used by the Transcarpathians within the community to express solidarity among themselves: when the term "we" includes the speaker and the listener alike. A research as an unreal, unusual, and formal situation and the interviewers who were usually strangers for the respondents did not mean solidarity but formalism. The designation "Budapest time", considered by 
Pisano and Simonyi (2016) as typical, is not characteristic of the population of Transcarpathia. Referring to CET as "Budapest time" occurs among outsiders. For Transcarpathians, this is not foreign, not Budapest time but their own, local time.

To summarize, the following map (Figure 6) shows the percentage of the respondents who answered local (CET) time to the interviewer at the beginning of the inquiry. In a separate column, we have provided answers of the respondents who filled the questionnaire in Ukrainian and in Hungarian. In five districts (Irshava/ Ilosva, Velykyi Bereznyi/Nagyberezna, Mizhhiria/Ökörmező, Perechyn/Perecseny, and Volovets/Volóc), there was no query in Hungarian because in these districts the proportion and number of Hungarians is very low. The map clearly shows that the local time (CET) is used in all parts of Transcarpathia. A much wider circle of respondents uses CET than expected, as according to Pisano and Simonyi (2016). For that matter, for those living in the eastern, north-eastern part of the region, in a mountainous area, drawing a time zone based on geographical grounds instead of political ones would justify the use of EET rather than CET since (as shown in Figure 1) geographically only a very small, western part of the region slips to CET, and most of Transcarpathia belongs to EET in geographical terms (as well). The region is thus the borderland of EET and CET, the periphery of both time zones.

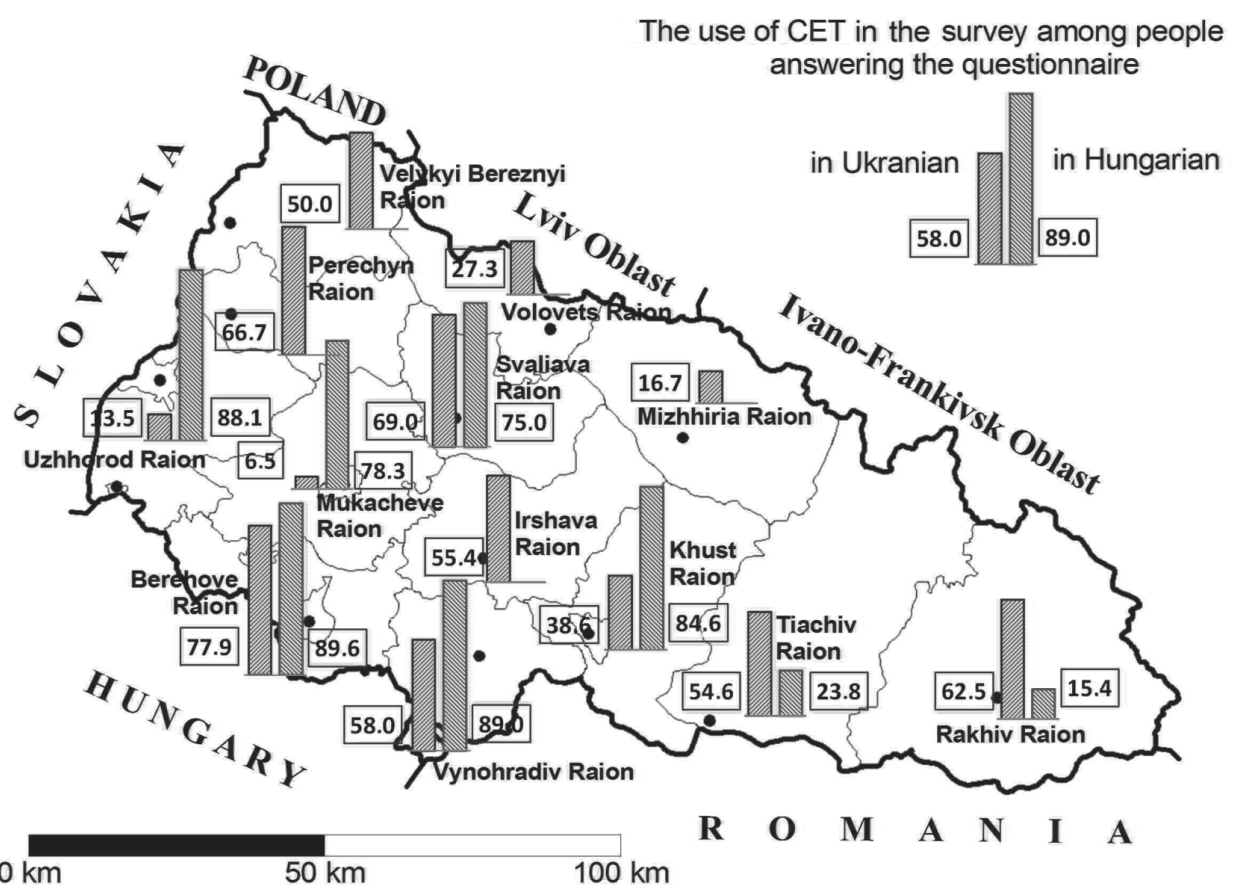

Figure 6. Proportion of the users of local time in the Transcarpathian districts based on the Tandem 2016 sociological survey (\%) 
Pisano and Simonyi's theory (Pisano and Simonyi 2016) on Hungarians does not fully explain either why Hungarians living in the region use CET. If they were using CET only because of their belonging to the Hungarians or their attachment to the Hungarian world, we could expect to observe a similar phenomenon among the slightly more southern Hungarians in Romania. But this is not the case: Hungarians in Romania, south of Transcarpathia, use the official Romanian time uniformly, which corresponds to EET.

\section{Conclusions}

Stroschein (2012: 93) assumes that "ethnic Hungarians living there operate on 'Hungarian time', meaning that their clocks run one hour behind 'Ukrainian time"”. According to Pisano and Simonyi (2016: 43-44), CET differing from the official EET is used by Hungarian speakers, and Slavs living a rural lifestyle in the mountains. The former use it because it links them to Hungary, the Hungarian world, and the latter do so because CET suits better the mountainous agricultural lifestyle than EET. However, we showed that the use of local time is not differentiated on an ethnic basis but by the fact that "native", "original inhabitants" (the local population, who has lived in the region for at least one generation, regardless of their ethnic, religious origin) use it, while firstgeneration "immigrants" (population from elsewhere, mostly Ukraine's other regions) do not.

In this paper, based on the data of an empirical sociological research, the analysis of the linguistic landscapes of six Transcarpathian cities, we have illustrated that in south-west Ukraine, Transcarpathia, a significant part of the population - regardless of ethnicity - live their lives not according to the official Kyiv time (EET) but according to the informal local time (CET). On the basis of the empirical quantitative study of the linguistic landscapes of six Transcarpathian cities, it has been confirmed that the coexistence of official Kyiv time and unofficial local time appears in the public space, too. Even the names of the two times are distinguished in the local language use in Ukrainian, Hungarian, and Russian languages alike. From the qualitative analysis of the elements of linguistic landscape, we have come to the conclusion that in the formal posts related to the state (unmarked) Kyiv time dominates, while in the informal trade, non-governmental and private inscriptions Kyiv time and local time are displayed simultaneously, often together. It is also common that Kyiv time appears indicated: a comment or abbreviation indicates how to interpret the specified time.

Time zones are adjusted to political boundaries. For political, economic, and ideological reasons, states determine which areas to include under which 
time zones based on the logic of the nation-state rather than that of geography. Transcarpathia is an example proving that symbolic value and tradition are stronger than political ideology.

\section{References}

Backhaus, Peter. 2006. Multilingualism in Tokyo: A look into the linguistic landscape. In Durk Gorter (ed.), Linguistic Landscape: A New Approach to Multilingualism, 52-66. Clevedon: Multilingual Matters.

Balla, Károly D. 1993. Amikor Kárpátalján a Big Ben szerint harangoztak [When Transcarpathian bells rang as the Big Ben]. In Balla Károly D. (ed.), Kis(ebbségi) magyar skizofrénia [Little Hungarian Minority Schizophrenia], 83-89. UngvárBudapest: Galéria Kiadó.

Batt, Judy. 2002. Transcarpathia: Peripheral region at the 'centre of Europe'. Regional \& Federal Studies 12(2): 155-177.

Ben-Rafael, Eliezer. 2009. A sociological approach to the study of linguistic landscapes. In Elana Shohamy-Durk Gorter (eds.), Linguistic Landscape: Expanding the Scenery, 40-54. London: Routledge.

Beregszászi, Anikó-Csernicskó, István. 2019. Different states, same practices: Visual construction of language policy on banknotes in the territory of presentday Transcarpathia. Language Policy 18(2): 269-293. https://doi.org/10.1007/ s10993-018-9485-3.

Boiko, V.-Ditchuk I.-Zastavetska, L. 2016. Geografija: pidruchyk dlja 8 klasiv zagal'noosvitnih navchal'nyh zakladiv [Geography: A Textbook for the $8^{\text {th }}$ Form]. Kam’janec'-Podil's'kyj: Abetka.

Csernicskó, István. 1998. A magyar nyelv Ukrajnában (Kárpátalján) [The Hungarian Language in Ukraine (Transcarpathia)]. Budapest: Osiris.

- 2005. Hungarian in Ukraine. In Anna Fenyvesi (ed.), Hungarian Language Contact Outside Hungary: Studies on Hungarian as a Minority Language, 89131. Amsterdam/Philadelphia: John Benjamins Publishing Company.

— 2017. Nyelv, nyelvtudás és nyelvhasználat Kárpátalján a Tandem 2016 kutatás adatai alapján [Languages, language skills, and language use in Transcarpathia based on the data of Tandem 2016]. Kisebbségi Szemle II(2): 41-63.

Csernicskó, István-Ferenc, Viktória. 2014. Hegemonic, regional, minority and language policy in Subcarpathia: A historical overview and the present-day situation. Nationalities Papers 42(3): 399-425.

Csernicskó, István-Petteri Laihonen. 2016. Hybrid practices meet nationstate language policies: Transcarpathia in the twentieth century and today. Multilingua: Journal of Cross-Cultural and Interlanguage Communication 35(1): 1-30. 
Fedinec, Csilla-Csernicskó, István. 2017. Hány az óra, Vekker úr? Időzónák és politika Kárpátalján [What time is it, Mr Alarm Clock? Time zones and politics in Transcarpathia]. Kommentár 2: 81-99.

Pisano, Jessica-Simonyi, André. 2016. Post-Soviet or Eurasian lands? Rethinking analytic categories in the Ukraine-EU and Russia-China borderlands. In Tone Bringa-Hege Toje (eds), Eurasian Borderlands: Spatializing Borders in the Aftermath of State Collapse, 27-58. New York: Palgrave Macmillan.

Stroschein, Sherill. 2012. Ethnic Struggle, Coexistence, and Democratization in Eastern Europe. Cambridge: Cambridge University Press. 